\title{
YIELD, QUALITY AND STABILITY EVALUATION OF THE EFFECT OF BIO FERTILIZER APPLICATION ON SUGAR BEET UNDER IRRIGATION SYSTEMS IN NEWLY RECLAIMED SANDY SOILS.
}

\author{
Thalooth, A.T.; Elham A. Badr; Howida, H. Khedr
}

Field Crops Research Department, National Research Centre, Dokki, Egypt.

DOI: 10.46609/IJAER.2020.v06i02.004 URL: https://doi.org/10.46609/IJAER.2020.v06i02.004

\begin{abstract}
Field experiment was carried out at the experimental farm of the Agricultural Research Station, National Research Centre El-Nubaria district, Egypt during the winter season of 2016/2017 to evaluate the effect of foliar application of humic acid and yeast as bio fertilizer on yield and quality of sugar beet under two method of water irrigation ( Surface and subsurface).Results showed that subsurface irrigation was more efficient than surface irrigation. The results also indicate that dual application of humic acid and yeast have promoting effect than single one and such effect was more pronounced under subsurface irrigation.
\end{abstract}

Keywords: Sugar beet, Yield, quality, Surface, Subsurface irrigation, Humic acid, Yeast

\section{INTRODUCTION}

Sugar beet (Beta vulgaris L.) is a member of the family Chenopodiaceae, is one of the most important sugar crops in the world. Sugar beet has a crucial importance in human nutrition and raw material of sugar. Sugar beet, grown as a feedstock for the production of pure sugar is one of the most important cash crops in the world. Now great attention is being devoted to search for advanced crop management techniques in agriculture and untraditional natural and safe stimulating growth substances to increase sugar beet productivity. Thus, possibilities of utilization of various biologically active matters such as humic acid and yeast for regulation of sugar beet growing process have been investigated. Water demand of sugar beet also has the most critical point to get a uniform yield. Pejic et al., (2011) reported that sugar beet cannot meet water requirement to provide its uniform development so that irrigation is a necessity in the development period and water demand of sugar beet .

Bio-fertilizers are formulations of beneficial microorganisms, which upon application can increase the availability of nutrients by their biological activity and help to improve the soil 
International Journal of Agriculture and Environmental Research

ISSN: 2455-6939

Volume: 06, Issue: 02 "March-April 2020"

health. Microorganisms secrete various plant growth and health promoting substances Pandya and Saraf,(2010). Bio-fertilizers are considered as a low cost, effective and renewable source of plant nutrients to supplement chemical fertilizers Boraste et al., (2009).Humic acid and yeast are considered bio-stimulants to enhance the yield and quality of sugar beet and they become positive factors that minimize utilization of inorganic and chemical fertilizers. They are safe for human and environment and using them was accompanied with reducing the great pollution occurred in our environment. Humic compounds occupy a key position because of their multifarious roles in maintaining improving soil fertility and positively affecting physiological functions of plant. the positive effects of humic acid on the growth and yield of sugar beet have been reported by Abd El Aal and Abd El-Rahman, (2014) and Rassam et al. (2015).

Yeast is a natural bio- product rich in proteins, carbohydrates, minerals and vitamins, beside, hormones and other growth regulating substances Nagodawithana,(1991). Yeasts represent an abundant and dependable source of bioactive and chemically novel compounds. Boraste et al.,( 2009) mentioned that yeasts synthesize antimicrobial and other useful substances required for plant growth from amino acids and sugars secreted by bacteria, organic matter and plant roots A growing number of studies indicate that plant root growth may be directly or indirectly enhanced by yeasts Boraste et al.,(2009).

The performance of sugar beet plants depends not only on its genetic characteristics and nutrition but also on the surrounding environmental conditions particularly methods of irrigation and water supply. There are specific problems in the management of sandy soils including their excessive permeability, low water and nutrient holding capacities Suganya and Sivasamy,(2006). Therefore, managing the use of irrigation water and plant nutrients is a major challenge of sandy soil amelioration efforts. Recently, growers have to adopt modern techniques of cultivation, and improve water use efficiency (WUE) by systems irrigation of surface and subsurface..However, subsurface drip irrigation is considered to be the most modern irrigation system with efficient water delivery that can contribute immensely on improving crop water use efficiency and conserving water Hanson and May, (2004).

Therefore, the aim of this work is to study the effect of humic acid and yeast on the yield of sugar beet under surface and subsurface irrigation.

\section{MATERIAL AND METHODS}

Field experiment was carried out at the Agricultural Production and Research Station, National Research Centre, Nubaria Province, Behaira Governorate, Egypt, during the winter season of 2016/2017 to study the effect of foliar application of humic acid and yeast on yield of sugar beet plants under two method of water application. The study included six treatments which were the combination of two irrigation systems ( surface and subsurface irrigation) and three biofertilizer 
application ( Humic acid, yeast and combined application of humic and yeast). The experimental design was split block design with three replicates where the main plots allocated to method of system irrigation. Two drip irrigation systems (surface and subsurface) were constructed and tested before used in the experimental location. Laterals (16 mm diameter, P.E.) and the emitters were built-in with an average discharge $4.0 \mathrm{~L} / \mathrm{h}$ and $0.3 \mathrm{~m}$ emitter spacing. The subsurface drip irrigation system was installed before the crop seeding, where its laterals (16 mm drip-lines) were buried $0.6 \mathrm{~m}$ apart at $15 \mathrm{~cm}$ below soil surface so that they are not affected by the cultivation practices during the current growing season. The surface soil sample (0-30 depth) of the experimental area was subjected to laboratory analysis to determine some of its physical and chemical properties according to the method described by Chapman and Pratt (1982) in Table (1).

Table 1: Mechanical and chemical analysis of experimental soil.

\begin{tabular}{|ll|ll|}
\hline \multicolumn{2}{|l|}{ Mechanical analysis } & Chemical analysis \\
\hline Sand \% & 91.2 & Organic matter\% & 0.3 \\
\hline Slit \% & 4.0 & E.C mmhos/cm3 & 0.3 \\
\hline Clay \% & 4.8 & $\mathrm{pH}$ & 7.4 \\
\hline $\mathrm{CaCo}_{3}$ & 1.3 & Soluble N ppm & 7.7 \\
\hline Soil Texture & Sandy & Available P ppm & 2.9 \\
\hline & & Exchange K ppm & 19.8 \\
\hline
\end{tabular}

Sugar beet variety Chenopodiaceae c.v (Sirana) was sown In the first week of November 2016. Each plot were divided to three sub plots and subjected to the following. treatment: (1) plants treated with humic acid at level of (2 gm/ liter) (2) plants treated with yeast at level of $(32 \mathrm{gm} /$ liter) and (3) plants treated with both humic acid at level of (1 gm/ litre) and yeast at level of (16 gm/ litre). Treatments carried out after one month of sowing at volume of 200 liter per feddan. The normal agriculture practices of growing sugar beet were practiced till harvest as recommended.

At harvest time, one square meter was taken at random from the three replicates from each sub plot to determine root characters (length and diameter) $(\mathrm{cm})$ and fresh weight of top ,root and total weight of top and roots (gm / plant ). Yield of top, root and total weight of top and roots $(\mathrm{Kg}$ and ton per fad) was also estimated. Three roots were chosen randomly from each sub plot to determine sucrose percentage as described by Le- Docte (1927). Sugar yield was obtained by multiplying sugar $\%$ by root yield. Potassium and Sodium were measured in the root dry 
International Journal of Agriculture and Environmental Research

ISSN: 2455-6939

Volume: 06, Issue: 02 "March-April 2020"

weight at harvest time, by using the Flame photometer. $\alpha$ Amino nitrogen was also calculated by double beam filter photometry using the blue number method Sheikh_Aleslami (1997) . Juice purity percentage $(\mathrm{QZ})$ was calculated as following $\mathrm{QZ}=\mathrm{ZB} / \mathrm{Pol}$.Impurities percentage \% calculated as the formula $=\{(\mathrm{K}+\mathrm{Na}) \times 0.0343)+($ alpha amino $-\mathrm{N} \times 0.094)+0.29\}$ as described by Carruthers et.,al.(1962). White sugar contents were calculated using the formula of Reinefeld et al. (1974): WSC = SC-MS- SFL. White sugar yield (WSY) = root yield (RY) * WSC. The results were submitted to analysis of variance according to Snedecor and Cochran (1982). Differences among treatment means were determined using the LSD test at a significance level of 0.05 .

\section{RESULTS AND DISCUSSION}

\section{A. Yield and yield components:}

\section{Effect of methods of water irrigation:}

Data presented in Table (2) clearly show that root length $(\mathrm{cm})$,root diameter $(\mathrm{cm})$, fresh weight of root and top(gm), root, top and sugar yield(ton/fed)and white sugar yield (ton/fed) all studied characters slightly affected by method of water irrigation, however little increase recorded by subsurface drip irrigation than surface drip irrigation. The ability of subsurface drip irrigation to improve roots yield could be attributed to the less water lost from soil surface through evaporation, which resulted in optimum crop yield. Moreover, subsurface drip irrigation allows maintenance of optimum soil moisture content in the root zone, which improved the efficiency of water and fertilizers use .These results were in agreement with those obtained by SakellariouMakrantonaki et al (2002a+b), Kassab et al (2005),Abo EL-Soud(2009), Hassanli et al. (2009), Selim et al (2009) and El-Noemani et al (2015) who reported that using of subsurface irrigation systems achieved the longest roots. Such effect results from enhancing cell division and enlargement which need more water supplies

\section{Effect of foliar application:}

The data presented in Table (2) clearly indicate that Irrespective effect of method of water irrigation, root parameters such as length, diameter and fresh weight of root and top significantly enhanced by yeast application as compared with humic acid. These results were in the same line with the findings of Shalaby and El-Nady (2008) and Nemeat Alla (2016). The obvious effect of yeast on root parameters may be attributed to the effect of yeast cytokinins that result in enhancing the accumulation of soluble metabolites Muller and Leopold,(1966). Such promoting effect of yeast resulted from the active biological substance produced by yeast such as auxins, gibberellins, cytokinins, amino acids and vitamins Bahr and Gomaa, (2002).These results confirmed by the record obtained by of Mekki and Ahmed (2005) and Agamy et al. (2013).The 
same table also show that dual application of humic acid and yeast surpass the single effect of either yeast or humic acid . Such obvious effect of combined application of humic acid and yeast may be resulted from the collective effect of both of them. In this respect, Shehata et al. (2012), mentioned that yeast as a natural bio-substance has stimulating, nutritional and protective functions resulting from its enriched content with the sources of phyto-hormones especially cytokinins, vitamins, enzymes, amino acids and minerals. The enhancing effect of humic acid resulted from its promoting effect in increasing nutrient uptake of plants which affect membrane permeability Zientara, (1983). Nardi et al. (2002) and Eyheraguibel et al. (2008) also reported that humic acid may have various biochemical effects either at cell wall, membrane level or in the cytoplasm. The positive effect of dual application supported by the results gained by Dina et al., (2013) and Fatma et al. (2015) who reported that application of yeast extract plus humic acid increased vegetative growth parameters. In the same table (2) show that yeast resulted in clear increment of sugar yield (root ,top, sugar and white sugar yield(ton/fed)) as compared by humic application. These results obviously show that yeast records exceed that of humic acid effect. The positive effects of humic acid supported by El-Bassiouny et al (2014) and Oliver and Nelsan(2013) who reported that humic acid induce translocation of trace elements directly to metabolic sites in plant cell and thus maximizing the plants productive capacity.

Table 2: Effect of method of water irrigation and foliar application on root characters and yield components of sugar beet plants

\begin{tabular}{|c|c|c|c|c|c|c|c|c|}
\hline \multirow{2}{*}{$\begin{array}{l}\text { Treatment } \\
\text { Water irrigation }\end{array}$} & \multicolumn{2}{|c|}{ Root characters } & \multicolumn{2}{|c|}{ Fresh weight /plant } & \multicolumn{4}{|c|}{$\begin{array}{c}\text { Sugar yield } \\
\text { (ton/fed) }\end{array}$} \\
\hline & $\begin{array}{l}\text { Root } \\
\text { Length } \\
(\mathrm{cm})\end{array}$ & $\begin{array}{l}\text { Root } \\
\text { Diameter } \\
(\mathrm{cm})\end{array}$ & $\begin{array}{l}\text { Root } \\
\text { (gm) }\end{array}$ & $\begin{array}{l}\text { Top } \\
\text { (gm) }\end{array}$ & $\begin{array}{l}\text { Root } \\
\text { yield } \\
\text { (ton/fed) }\end{array}$ & $\begin{array}{l}\text { Top } \\
\text { yield } \\
\text { (ton/fed) }\end{array}$ & $\begin{array}{l}\text { Sugar } \\
\text { Yield } \\
\text { (ton/fed) }\end{array}$ & $\begin{array}{l}\text { White } \\
\text { Sugar } \\
\text { (ton/fed) }\end{array}$ \\
\hline Surface & 36.11 & 7.89 & 1014.44 & 265.56 & 16.21 & 5.51 & 1.96 & 2.43 \\
\hline Subsurface & 36.44 & 8.22 & 1124.44 & 275.56 & 20.12 & 7.06 & 2.57 & 3.20 \\
\hline LSD 5\% & 0.83 & 0.31 & 79.76 & 25.33 & 1.33 & 0.33 & 0.21 & 0.11 \\
\hline \multicolumn{9}{|c|}{ Foliar application } \\
\hline Humic acid & 32.33 & 7.17 & 923.33 & 190.83 & 13.21 & 5.96 & 1.61 & 2.06 \\
\hline Yeast & 37.33 & 7.17 & 1093.33 & 290.00 & 19.57 & 6.20 & 2.40 & 2.97 \\
\hline Humic +yeast & 39.17 & 9.83 & 1191.67 & 330.83 & 21.71 & 6.70 & 2.79 & 3.42 \\
\hline LSD5\% & 3.15 & 0.80 & 89.01 & 33.19 & 1.24 & 0.56 & 0.19 & 0.23 \\
\hline
\end{tabular}




\section{B. Interaction effect of method of water irrigation and foliar application on root characters and yield components of sugar beet plants}

The present study showed that either root length or diameter significantly response to method of water irrigation and foliar application treatment. However, the highest root length and diameter $(39.33$ and $10 \mathrm{~cm}$ ) respectively obtained by sugar beet plants foliar sprayed with both yeast and humic acid under subsurface irrigation (Table 3).Also showed that root and top fresh weight similarly affected by the interaction effect of water irrigation and foliar application with yeast and humic acid . It is clearly also observed that the highest record of top and root ( 336.67 and $1256.67 \mathrm{gm}$ ) respectively resulted by combined application of yeast and humic under subsurface irrigation. According to the data presented in Table (3), it is clearly indicated that the interaction effect of dual application with humic and yeast under subsurface irrigation surpassed the other interactions. Subsurface irrigation was associated with higher yield quantity than surface drip irrigation. Such effect resulted in more pronounced values for root, top and total sugar yield (7.87,24.39 and $32.26 \mathrm{ton} / \mathrm{fad})$ respectively. The enhanced effect of combined application of humic acid and yeast under subsurface irrigation supported by the results of Selim et al (2009) and Qin et al (2019) . These results could be attributed to the improvement of the moisture retention and nutrient supply potentials of sandy soils after humic substances application.

In the same table is clearly indicated that dual application of yeast and humic acid under subsurface irrigation has promoting effect on sugar yield as well as white sugar yield (ton/ fad).The examined data obviously show strong correlation between sugar yield and white sugar yield with all important sugar beet parameters. These results were in line with those obtained by Sadeghi-Shoae et al. (2013) .The same table also show that the highest sugar yield as well as white sugar yield gained by sugar beet plants foliar sprayed by both yeast and humic under subsurface irrigation (3.93 and 3.19 ton/fad) respectively.

\section{Table 3: Interaction effect of method of water irrigation and foliar application on root characters and yield components of sugar beet plants}

\begin{tabular}{|c|c|c|c|c|c|c|c|c|c|}
\hline Treatment & Treatment & Root cl & acters & Fresh & eight/plant & \multicolumn{4}{|c|}{$\begin{array}{c}\text { Sugar yield } \\
\text { (ton/fed) }\end{array}$} \\
\hline Water irrigation & Foliar application & $\begin{array}{l}\text { Root } \\
\text { Length } \\
(\mathrm{cm})\end{array}$ & $\begin{array}{l}\text { Root } \\
\text { Diameter } \\
(\mathrm{cm})\end{array}$ & $\begin{array}{l}\text { Root } \\
\text { (gm) }\end{array}$ & $\begin{array}{l}\text { Top } \\
\text { (gm) }\end{array}$ & $\begin{array}{l}\text { Root } \\
\text { yield } \\
\text { (ton/fed) }\end{array}$ & $\begin{array}{l}\text { Top } \\
\text { yield } \\
\text { (ton/fed) }\end{array}$ & $\begin{array}{l}\text { Sugar } \\
\text { Yield } \\
\text { (ton/fed) }\end{array}$ & $\begin{array}{l}\text { White } \\
\text { Sugar } \\
\text { (ton/fed) }\end{array}$ \\
\hline
\end{tabular}


International Journal of Agriculture and Environmental Research

ISSN: 2455-6939

Volume: 06, Issue: 02 "March-April 2020"

\begin{tabular}{|l|l|l|l|l|l|l|l|l|l|}
\hline Surface & Humic acid & 32.33 & 7.00 & 843.33 & 188.33 & 12.20 & 5.50 & 1.89 & 1.48 \\
\cline { 2 - 9 } & Yeast & 37.00 & 7.00 & 1073.33 & 283.33 & 17.39 & 5.50 & 2.49 & 2.02 \\
\cline { 2 - 9 } & Humic +yeast & 39.00 & 9.67 & 1126.67 & 325.00 & 19.03 & 5.53 & 2.91 & 2.39 \\
\hline Subsurface & Humic acid & 32.33 & 7.33 & 1003.33 & 193.33 & 14.22 & 6.41 & 2.23 & 1.74 \\
\cline { 2 - 10 } & Yeast & 37.67 & 7.33 & 1113.33 & 296.67 & 21.75 & 6.90 & 3.45 & 2.79 \\
\cline { 2 - 10 } & Humic +yeast & 39.33 & 10.00 & 1256.67 & 336.67 & 24.39 & 7.87 & 3.93 & 3.13 \\
\hline
\end{tabular}

\section{Quality traits:}

It is interestingly known that sugar beet quality determined by both sugar concentration and other constituents that impair white sugar recovery such as potassium, sodium, amino acids and other nitrogenous compounds. According to the data presented in Fig(1,2) it is clearly show that there was few difference among treatments on purity and impurity percentage except slight increase in impurity under humic acid. These results confirmed by the results obtained by Sharaf (2012), Gobarah and Mekki (2005), Ahmed et al. (2012),Hozayn et al (2013) and Alice et al.,(2019).

The data presented in Table (4) show that dual application of yeast and humic under subsurface irrigation resulted on slight positive effect on purity percentage. Hence, impurities values are indicator for quality of sugar beet roots including ( $\mathrm{K}, \mathrm{Na}$ and $\alpha-\mathrm{N})$, the data collected in Table (4) indicate that the high record of purity with combined application of yeast and humic under subsurface irrigation may be probably due to it contains fewer values in the most of impurity parameters. In this respect Fortun et al (2006) reported that comparing with surface drip irrigation, subsurface drip irrigation improved the studied quality indicators. 
International Journal of Agriculture and Environmental Research

ISSN: 2455-6939

Volume: 06, Issue: 02 "March-April 2020"

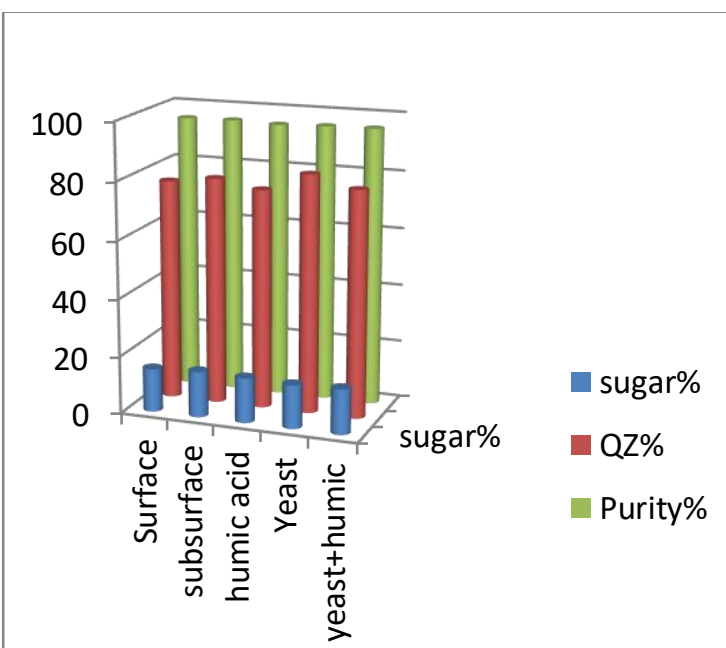

Fig 1: The effect of method of water irrigation and foliar application on root quality

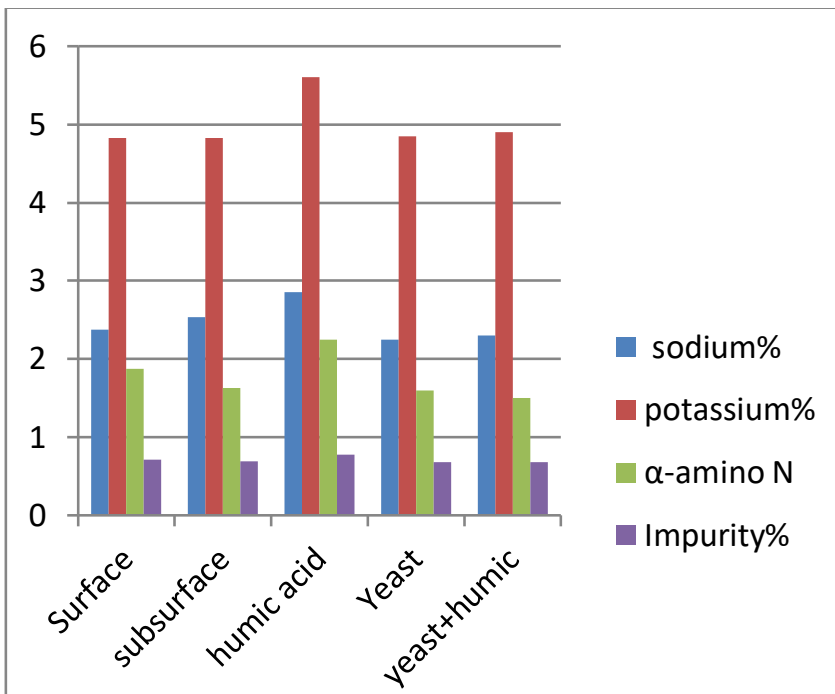

Fig 2: The effect of method of water irrigation and foliar application on root quality

Table 4: Interaction effect of method of water irrigation and foliar application on root quality

\begin{tabular}{|l|l|l|l|l|l|l|l|l|}
\hline Water irrigation & $\begin{array}{l}\text { Foliar } \\
\text { application }\end{array}$ & $\begin{array}{l}\text { Sugar } \\
\%\end{array}$ & $\begin{array}{l}\text { Sodium } \\
\%\end{array}$ & $\begin{array}{l}\text { Potassium } \\
\%\end{array}$ & $\begin{array}{l}\alpha \text {-amino N } \\
\%\end{array}$ & $\begin{array}{l}\text { QZ\% } \\
\%\end{array}$ & $\begin{array}{l}\text { Impurty } \\
\%\end{array}$ & $\begin{array}{l}\text { Purity } \\
\%\end{array}$ \\
\hline Surface & Humic acid & 15.5 & 2.6 & 5.6 & 2.6 & 72.68 & 0.82 & 94.74 \\
\hline & yeast & 14.3 & 2.1 & 4.5 & 1.5 & 82.89 & 0.66 & 95.40 \\
\hline & Yeast+humic & 15.3 & 2.4 & 4.4 & 1.5 & 73.68 & 0.66 & 95.66 \\
\hline Subsurface & Humic acid & 15.66 & 3.10 & 5.60 & 1.90 & 78.93 & 0.75 & 95.19 \\
\hline & yeast & 15.86 & 2.40 & 5.20 & 1.70 & 81.69 & 0.71 & 95.52 \\
\hline & Yeast+humic & 16.11 & 2.20 & 5.40 & 1.50 & 83.01 & 0.69 & 95.71 \\
\hline
\end{tabular}

\section{CONCLUSION}

Based on the obtained results of root yield, top yield, sugar yield and white sugar yield significantly affected with irrigation techniques. It can be concluded that subsurface drip irrigation was more efficient than surface drip irrigation on enhancing quantitative and 
International Journal of Agriculture and Environmental Research

ISSN: 2455-6939

Volume: 06, Issue: 02 "March-April 2020"

qualitative yield parameters of sugar beet. In addition, dual application of humic acid and yeast had significant effect on improving sugar beet yield as well as quality. Our findings also revealed that subsurface drip irrigation design in combination with dual application of humic acid and yeast is the most advantageous for sugar beet yield and quality in sand soil areas.

\section{REFERENCES}

Abd El-Aal, M.M.M. and H.M. Abd El-Rahman, 2014. Impact of PGPR and inorganic fertilization on growth and productivity of sweet ananas melon. International Journal of Agricultural Science and Research (IJASR), 4 (3):11-26.

Abo EL-Soud, H.M.A., 2009. Studies on water and salt movement under surface and drip irrigation systems in nile delta soils.. A Thesis submitted in partial Fulfillment of the Requirement for the Degree of Master of Science (Agric). Department of Soil, Faculty of Agriculture, University of Mansoura.

Agamay, R., H. Mohamed and A. Saad, 2013. Effect of soil amendment with yeasts as biofertilizers on the growth and productivity of sugar beet. African Journal of Agricultural Research Vol. 8(1), pp. 46-56.

Ahmed, S., M. Zubair, N. Iqbal, N.M. Cheema and K. Mahmood, 2012. Evaluation of sugar beet hybrid varieties under ThalKumbi in Pakistan. J. Agric. Biol., 14(4):605-608.

Alice T. Thalooth, M.M. Tawfik, Elham A. Badre and Magda H. Mohamed,2019. Yield and quality response of some sugar beet (Beta vulgaris L.) varieties to humic acid and yeast application in newly reclaimed soil. Middle East Journal of Agriculture 8(1):56-65.

Bahr, A.A., A.M. Gomaa, 2002. The integrated system of bio-and organic fertilizers for improving growth and yield of triticale. Egypt. J. Appl. Sci. 17(10):512-523.

Boraste, A., K.K. Vamsi, A. Jhadav, Y. Khairnar, N. Gupta, S. Trivedi, P. Patil, G. Gupta, M. Gupta, A.K. Mujapara and B. Joshi, 2009. Bio-fertilizers: A novel tool for agriculture. Int. J. Microbiol. Res., 1(2):23-31.

Carruthers, A., J.F.T. Oldfield and H.J. Teague, 1962. Assessment of beet quality. In The $15^{\text {th }}$ Annual Technical Conference. British Sugar Corporation Ltd., p. 28.

Chapman, H.D. and Pratt, P.F. (Eds.), 1982. Methods of Analysis for Soil, Plants and Waters. Div. of Agr. Sci., Univ. of Calif, Berkeley, CA.

Dina, S.S., A.H. Ibrahim; A.E.K. Nour El-Deen and A.M.M. Fatma, 2013. Induction of Systemic Resistance in Sugar-Beet Infected with Meloidogyne incognita by Humic Acid, 
International Journal of Agriculture and Environmental Research

ISSN: 2455-6939

Volume: 06, Issue: 02 "March-April 2020"

Hydrogen Peroxide, Thiamine and two amino acids, Egypt. J. Agronematol., Vol. 12, No.1, PP. 22-41.

El-Bassiouny, H.S.M., A.B. Bakry, A.A. Attia and M.M. Abd Allah, 2014. Physiological Role of Humic Acid and Nicotinamide on Improving Plant Growth, Yield, and Mineral Nutrient of Wheat (Triticum durum) Grown under Newly Reclaimed Sandy Soil, Agricultural Sciences, 5(8): 687700.

El-Noemani, A. A, Aboellil, , A. A.A and Dewedar, O.M., 2015. Influence of irrigation systems and water treatments on growth, yield, quality and water use efficiency of bean ( Phaseolus vulgaris L. ) plants . Int.J. ChemTech Res., 8(12), pp 248-258

Eyheraguibel, B., J. Silvestre and P. Morard, 2008. Effects of humic substances derived from organic waste enhancement on the growth and mineral nutrition of maize. Bioresour Technol., 99:42064212.

Fatma, K.M. Shaaban, M.M. Morsey and Thanaa Sh. M. Mahmoud, 2015. Influence of spraying yeast extract and humic acid on fruit maturity stage and storability of "Canino" apricot fruits. Int. J. Chem. Tech. Res.,8(6), pp 530-54.

Fortun, A., Benayas, J. and Fortun, C., 2006. The effects of fulvic and humic substances on soil aggregation: a micromorphological study. Eur. J. Soil Sci. 41, 563-572.

Gobarah, M.E. and B.B. Mekki, 2005. Influence of boron application on yield and juice quality of some sugar beet cultivars grown under saline soil conditions. Journal of Applied Sciences Research, 1(5): 373-379.

Hanson, B. and May, D., 2004. Effect of subsurface drip irrigation on processing tomato yield, water table depth, soil salinity, and profitability. Agric. Water Manag. 68, 1-17.

Hassanli, A.M, Ahmadirad Sh. and Beecham S. 2009. Evaluation of the influence of irrigation methods and water quality on sugar beet yield and water use efficiency. Agricultural Water Management $97: 357-362$.

Hozayn, M., 2013. Screening of some exotic sugar beet cultivars grown under newly reclaimed sandy soil for yield and sugar quality traits. J. Appl. Sci. Res., 9(3): 2213-2222.

Kassab, O.M., El-Noemani AA. and El-Zeiny H.A .2005. Influence of Some Irrigation Systems and Water Regimes on Growth and Yield of Sesame Plants Journal of Agronomy 4 (3): 220-224.

Le-Docte, A., 1927. Commercial determination of sugar beet in the beet roots using Sachs LeDocte process. International Sugar Journal 29: 488492. 
International Journal of Agriculture and Environmental Research

ISSN: 2455-6939

Volume: 06, Issue: 02 "March-April 2020"

Mekki, B.B. and A.G. Ahmed, 2005. Growth, Yield and Seed Quality of Soybean (Glycine max L.) As Affected by Organic, Bio-fertilizer and Yeast Application. Res. J. Agric. Biol. Sci., 1(4):320324.

Muller, K. and A.C. Leopold, 1966. Correlative aging and transport of p32 in corn leaves under the influence of kinetin plant 68:167-185.

Nagodawithana, W.T., 1991. Yeast technology. Universal foods cooperation Milwauke, Wisconsin. Published by Van Nostrand, New York.

Nardi, S., D. Pizzeghello, A. Muscolo and A. Vianello, 2002. Physiological effects of humic substances on higher plants. Soil Biol. Biochem., 34:1527-1536.

Nemeata Alla, H.E.A., 2016. Yield and quality of sugar beet as affected by rates of nitrogen and yeast under the number of magnesium application. J. Plant Production, Mansoura Univ., 7 (8): 821 -828.

Oliver, R. K., K. Cedric and L. E. Nelson, 2013. Effect of soil adjustment with yeasts as biofertilizers on the growth and yield of sugar beet. International Journal of Manures and Fertilizers, 2(11): 424-433.

Pandya Urja and Saraf Meenu ,2010. Role of Single Fungal Isolates and Consortia as Plant Growth Promoters under Saline Conditions. Research journal of biotechnology 5(3):5-9 .

Pejić, B., B. Ćupina, M. Dimitrijević, S. Petrović, S. Milić, Dj.Krstić and G. Jaćimović, 2011. Response of sugar beet to water deficit. Romanian Agricultural Research, 28: 151-155

Qin Xi, Wenhao Lai, Youyuan Cui, Hailong Wu and Tingning Zhao 2019. Effect of Yeast Extract on Seedling Growth Promotion and Soil Improvement in Afforestation in a Semiarid Chestnut Soil Area. Forests, 10, 76,page: 1-16.

Rassam, G., D. Alireza, K.Y. Asghar and D. Maryam, 2015. Impact of Humic Acid on Yield and Quality of Sugar Beet (Beta vulgaris L.) Grown on Calcareous Soil. Not Sci Biol., 7(3):367-371.

Reinefeld, E., A. Emmerich, G. Baumgarten, C. Winner and U. Beiss, 1975. Zur voraussage des Melassezuckers aus Rubenanalysen. Zucker, 27:2-15.

Sadeghi-Shoae, M., F. Paknejad, H.H. Darvishi, H. Mozafari, M. Moharramzadeh and M.R. Tookalloo, 2013. Effect of intermittent furrow irrigation, humic acid and deficit irrigation on water use efficiency of sugar beet. Annals of Biological Research, 4(3):187-193. 
International Journal of Agriculture and Environmental Research

ISSN: 2455-6939

Volume: 06, Issue: 02 "March-April 2020"

Sakellariou-Makrantonaki, M., Kalfountzos and D., Vyrlas, P., 2002a. Water saving and yield increase of sugar beet with subsurface drip irrigation. Global Nest: Int. J. 4 (2-3), 85-91.

Sakellariou-Makrantonaki, M., Kalfountzos, D., Vyrlas, P. and Kapetanos, B., 2002b Water saving using modern irrigation methods. In: 3rd International Forum Integrated Water Management: The key to Sustainable Water Resources, Hydrorama, Athens, Greece, pp 96-102.

Selim, E.M., Mosa A.A. and El-Ghamry A.M. 2009. Evaluation of humic substances fertigation through surface and subsurface drip irrigation systems on potato grown under Egyptian sandy soil conditions. Agricultural Water Management 96 (2009) 1218-1222.

Shalaby, M. El-Sayed and El-Nady M. Fathi, 2008. Application of Saccharomyces cerevisiae as a biocontrol agent against Fusarium infection of sugar beet plants. Acta Biologica Szegediensis, 52(2):271-275.

Sharaf, E.A.A.M., 2012. Effect of some agricultural and biological treatments on sugar beet production. Ph. D. Thesis Fac. of Agric. Assiut. Uni., Egypt.

Shehata, S.A., Z.F. Fawzy and H.R. El-Ramady, 2012. Response of Cucumber Plants to Foliar Application of Chitosan and Yeast under Greenhouse Conditions. Australian Journal of Basic and Applied Sciences, 6(4):63-71.

Sheikh Aleslami, R., 1997. Laboratorial Methods and their Application to Control Food and Sugar Industries Process. Mersa Publications, Tehran, Iran.

Snedecor, G.W. and W.G. Cochran, 1982. Statistical Methods" 7th ed., Iowa Stat. Univ. Press, Ames, Iowa, USA.

Suganya, S. and Sivasamy, R., 2006. Moisture retention and cation exchange capacity of sandy soil as influenced by soil additives. J. Appl. Sci. Res. 2, 949-951

Zientara, M., 1983. Effect of sodium humate on membrane potential in internodal cells of Nitellopsis obtuse. Acta Societatis Botanicorum Poloniae, 52: 271-277 